\title{
Analisis Kesalahan Siswa Dalam Menyelesaikan Soal Pemecahan Masalah Matematika Berdasarkan Teori Newman
}

\author{
Ririn Rahmawati ${ }^{1, a}$, Fertilia Ikashaum ${ }^{2}$ \\ ${ }^{1,2}$ Tadris Matematika, FTIK, IAIN Metro, \\ Jalan Ki. Hajar Dewantara 15 A Iring Mulyo Metro Timur Kota Metro 34111 \\ e-mail: aririririnrahma2004@gmail.com
}

\begin{abstract}
Problem solving ability is one of the mathematical abilities that need to be mastered by students to equip students in logical, analytical, systematic thinking and the ability to work well together. In addition, this problem solving ability is very important for students to train students in solving problems in everyday life. This study aims to analyze student errors in solving mathematical problem solving problems based on Newman's theory. The type of research used is descriptive qualitative. The subjects of this study were students of class VII-A SMP Muhammadiyah 1 Menggala. Data collection used in the form of tests, interviews and documentation. The results showed that the most mistakes made by students were in writing the final answer, which was caused because students did not understand the commands in the questions well. The second most common error is the transformation error caused because students do not have the skills to change the language of the problem into a mathematical model. The third error, namely misunderstanding the problem caused by students not being careful in writing down the information in the problem, and not getting used to writing down the information in the problem when solving math problems. The fourth error, namely the error of process skills caused by students not being careful in carrying out the calculation process
\end{abstract}

Keywords : Student Errors, Mathematical Problem Solving, Newman Analysis.

\begin{abstract}
Abstrak
Kemampuan pemecahan masalah merupakan salah satu kemampuan matematika yang perlu dikuasai siswa untuk membekali sisw dalam berfikir logis, analitis, sistematis dan kemampuan bekerja sama dengan baik. Selain itu kemampuan pemecahan masalah ini sangat pentung bagi siswa guna melatih siswa dalam menyelesaikan persoalan dalam kehidupan sehari-hari. Penelitian ini bertujuan untuk menganalisis kesalahan siswa dalam menyelesaikan soal pemecahan masalah matematika berdasarkan Teoi Newman. Jenis penelitian yang digunakan adalah deskriptif kualitatif. Subjek penelitian ini adalah siswa kelas VII-A SMP Muhammadiyah 1 Menggala. Pengumpulan data yang digunakan berupa tes, wawancara dan dokumentasi. Hasil penelitian menunjukan bahwa kesalahan yang paling banyak dilakukan siswa adalah pada penulisan jawaban akhir, yang disebabkan karena siswa
\end{abstract}


tidak memahami perintah yang ada di soal dengan baik. Kesalahan kedua yang paling banyak dilakukan yaitu kesalahan transformasi yang disebabkan karena siswa tidak memiliki keterampilan dalam mengubah bahasa soal kedalam model matematika. Kesalahan ketiga, yaitu kesalahan memahami masalah yang disebabkan karena siswa kurang teliti dalam menuliskan informasi yang ada di soal, dan tidak terbiasa menuliskan informasi yang ada di soal pada saat menyelesaikan soal matematika. Kesalahan keempat, yaitu kesalahan keterampilan proses yang disebabkan karena siswa kurang teliti dalam melakukan proses perhitungan.

Kata kunci : Kesalahan siswa, Pemecahan Masalah Matematika, Analisis Newman.

\section{PENDAHULUAN}

Matematika merupakan suatu ilmu pengetahuan yang erat kaitannya dengan aspek kehidupan sehari-hari serta memiliki peranan penting dalam perkembangan ilmu pengetahuan[1]. Peranan matematika tersebut dapat dilihat dari dua sisi, yaitu sisi kehidupan praktis dan sisi matematika sebagai proses berfikir. Dari sisi kehidupan praktis, matematika digunakan dalam menjalankan berbagai aktivitas diantaranya melakukan transaksi jual beli, menghitung jumlah suatu barang, mengukur suatu benda, dan menyajikan informasi yang bersifat kuantitatif. Sedangkan dari sisi matematika sebagai proses, matematika berperan untuk melatih kemampuan berfikir logis dan analisis[2]. Mengingat akan pentingnya peran matematika dalam kehidupan, sudah seharusnya pembelajaran matematika mendapatkan perhatian lebih. Pembelajaran matematika hendaknya dirancang dengan baik agar siswa mampu mengembangkan kemampuan berfikir logis, analitis, kritis, sistematis, kreatif dan kemampuan bekerja sama. Selain kemampuan-kemampuan tersebut, ada beberapa kemampuan lain yang perlu dikuasai siswa dalam pembelajaran matematika, salah satunya adalah kemampuan pemecahan masalah.

NCTM mengemukakan bahwa pemecahan masalah merupakan bagian integral dari matematika sehingga tidak bisa dilepaskan dari pembelajaran matematika[3]. Kemampuan pemecahan masalah berarti 
proses menerapkan pengetahuan, keterampilan serta pemahaman yang telah dimiliki sebelumnya ke dalam situasi yang baru dengan mengandalkan pengetahuan yang telah dimiliki[4]. Kemampuan pemecahan masalah penting untuk dimiliki siswa guna melatih kemampuan dalam menyelesaikan persoalan kehidupan sehari-hari dan membekali siswa dalam menghadapi era globalisasi di masa yang akan datang[5]. Melalui pemecahan masalah siswa akan mendapatkan pengalaman belajar yang bermakana. Kebermaknaan tersebut akan tumbuh karena adanya keterlibatan siswa dalam menghubungkan konsep matematika yang telah dipelajari untuk menyelesaikan suatu masalah[6].

Pentingnya kemampuan pemecahan masalah bagi siswa justru tidak sejalan dengan fakta yang ada, yang menunjukan bahwa kemampuan pemecahan masalah siswa di Indonesia termasuk dalam kategori rendah. Rendahnya kemampuan siswa dalam menyelesaikan soal-soal pemecahan masalah ditunjukan dari hasil survei Programme for International Student Assessment (PISA) pada tahun 2018, yang menunjukan bahwa kemampuan matematika siswa Indonesia berada pada peringkat ke-74 dari 79 negara partisipan dengan rata-rata nilai sebesar 379. Angka ini menunjukan bahwa kemampuan matematika siswa yang meliputi kemampuan pemecahan masalah dan kemampuan penalaran masih dibawah rata-rata skor Internasional yaitu 500[7]. Data tersebut juga didukung dengan hasil survei Trend in Internasional Mathemtics and Science Study (TIMSS) pada tahun 2015, Indonesia berada di peringkat 44 dari total 49 negara partisipan, dengan rata-rata skor 397 jauh dibawah rata-rata skor Internasional yaitu 500. Jumlah ini menunjukan bahwa posisi Indonesia berada ke arah lebih dari rendah dengan kriteria TIMSS kategori rendah adalah 400[8]. Selain dari dua sumber yang disebutkan di atas, rendahnya kemampuan pemecahan masalah siswa juga didukung dari hasil penelitan yang dilakukan oleh Rizky Restiani Fatamala, Ratna Sariningsih dan Luvy Sylviana Zhanty pada tahun 2020 bahwa kemampuan pemecahan masalah matematika siswa tergolong rendah. Banyak siswa yang masih keliru dalam menentukan indikator 
pemecahan masalah, merencanakan penyelesaian dan melaksanakan penyelesaian, segingga membutuhkan upaya lebih untuk meningkatkan kemampuan pemecahan masalah matematis siswa[9].

Salah satu materi yang memuat masalah yang berkaitan dengan kehidupan sehari-hari adalah aritmatika sosial. Aritmatika sosial merupakan salah satu materi matematika yang diajarkan di tingkat SMP. Materi ini mempelajari tentang permasalahan yang berhubungan dengan kehidupan sehari-hari[10]. Adapun materi yang dipelajari dalam aritmatika sosial yaitu menghitung harga penjualan, harga pembelian, untung, rugi, diskon, pajak dan lain lain. Materi aritmatika sosial termasuk materi yang dianggap rumit bagi siswa, kerumitan tersebut secara umum diakibatkan karena kurangnya pemahaman siswa dalam memahami konsep, penguasaan operasi matematika dasar dan memahami soal itu sendiri[11]. Hal tersebut sejalan dengan hasil pra-survei yang dilakukan di SMP Muhammadiyah 1 menggala pada tanggal 12 Januari 2021, melaui wawancara dengan guru mata pelajaran dan studi dokumentasi terhadap hasil belajar siswa, diperoleh informasi bahwa pada saat pembelajaran dilakukan secara luring (luar jaringan) siswa cenderung bingung jika mengerjakan soal yang berbeda dengan contoh soal yang diberikan sebelumnya. Sedangkan pada saat pembelajaran dilakukan secara daring (dalam jaringan) siswa merasa kesulitan dalam memahami materi yang diberikan oleh guru, karena pembelajaran yang dilakukan hanya melalui apliksasi whatshapp, dimana siswa dituntut untuk memahami materi secara mandiri, dengan keterbatasan penjelasan dari guru. Hal tersebut membuat siswa banyak melakukan kesalahan dalam menyelesaikan soal pemecahan masalah matematika materi aritmatika sosial.

Salah satu cara yang dapat digunakan untuk mengetahui penyebab rendahnya kemampuan pemecahan masalah matematis siswa yaitu dengan menganalisis kesalahannya[12]. Analisis kesalahan dilakukan di SMP Muhammadiyah 1 menggala dengan alasan karena di sekolah tersebut belum pernah dilakukan penelitian untuk mengetahui kesalahan siswa dalam menyelesaikan soal-soal pemecahan masalah. 


\section{Hipotenusa}

Sehingga dalam proses pembelajaran guru sering merasa bingung dalam menentukan metode pembelajaran yang sesuai dengan keadaan siswa disekolah tersebut. Ada banyak metode atau cara yang dapat digunakan untuk menganalisis kesalahan siswa, salah satunya dengan menggunakan Teori Newman. Teori Newman dikenalkan pertama kali oleh Anne Newman seorang guru matematika di Australia pada tahun 1977[13]. Teori ini dirancang sebagai prosedur diagnostik sederhana dalam menyelesaikan pemecahan masalah matematis berbentuk cerita. Teori ini dipilih oleh Peneliti agar dapat mengungkap jenis kesalahan yang dilakukan oleh siswa dalam menyelesaikan soal pemecahan masalah secara lebih komprehensif, yaitu dari segi penguasaan linguistik atau kebahasaan maupun pengolahan matematika.

Berdasarkan uraian di atas, maka perlu dilakukan sebuah penelitian untuk mengetahui kesalahan siswa dalam menyelesaikan soal pemecahan masalah untuk meningkatkan hasil belajar siswa dan kemampuan pemecahan masalah siswa.

\section{METODE PENELITIAN}

Metode penelitian yang digunakan dalam penelitian ini adalah penelitian kualitatif deskriptif. Penelitian ini bertujuan untuk mengetahui kesalahan yang dilakukan siswa dalam menyelesaikan soal pemecahan masalah matematika berdasarkan Teori Newman. Penelitian ini dilakukan di SMP Muhammadiyah 1 Menggala dengan subjek penelitian adalah siswa kelas VII-A yang berjumlah 34 siswa. Teknik pengumpulan data yang digunakan dalam penelitian ini berupa tes uraian, wawancara dan dokumentasi. Tes uraian yang dimaksud dalam penelitian ini adalah tes yang memuat soal-soal pemecahan masalah dan uraian sebagai jawabannya.

Sebelum pengumpulan data dilakukan, instrumen tes telebih dahulu divalidasi oleh dua dosen matematika IAIN Metro. Setelah tes dinyatakan valid, soal diujicobakan kepada siswa kelas VIII-A SMP 


\section{Hipotenusa}

Journal of Research Mathematics Education VOL. 4 NO.2 2021

Muhammadiyah 1 Menggala untuk mengetahui validitas, reliabilitas, daya pembeda dan tingkat kesukarannya. Data hasil uji coba disajikan pada Tabel 1.

Table 1. Rekapitulasi Hasil Uji Coba Tes Kemampuan Pemecahan Maslah Matematis

\begin{tabular}{|c|c|c|c|c|}
\hline $\begin{array}{c}\text { No } \\
\text { Soal }\end{array}$ & Validitas & Reliabilitas & $\begin{array}{c}\text { Daya } \\
\text { Pembeda }\end{array}$ & $\begin{array}{c}\text { Tingkat } \\
\text { Kesukaran }\end{array}$ \\
\hline 1 & $\begin{array}{c}0,64 \\
\text { (Valid) }\end{array}$ & \multirow{5}{*}{$\begin{array}{c}0,84 \\
\text { (Reliabilitas } \\
\text { sangat tinggi) }\end{array}$} & $\begin{array}{c}0,29 \\
\text { (cukup) }\end{array}$ & $\begin{array}{c}0,55 \\
\text { (sedang) }\end{array}$ \\
\hline 2 & $\begin{array}{c}0,55 \\
\text { (Valid) }\end{array}$ & & $\begin{array}{c}0,20 \\
\text { (Cukup) }\end{array}$ & $\begin{array}{c}0,44 \\
\text { (sedang) }\end{array}$ \\
\hline 3 & $\begin{array}{c}0,88 \\
\text { (Valid) }\end{array}$ & & $\begin{array}{c}0,55 \\
\text { (Baik) }\end{array}$ & $\begin{array}{c}0,6 \\
\text { (sedang) }\end{array}$ \\
\hline 4 & $\begin{array}{c}0,87 \\
\text { (Valid) }\end{array}$ & & $\begin{array}{c}0,48 \\
\text { (Baik) }\end{array}$ & $\begin{array}{c}0,59 \\
\text { (sedang) }\end{array}$ \\
\hline 5 & $\begin{array}{c}0,93 \\
\text { (Valid) }\end{array}$ & & $\begin{array}{c}0,37 \\
\text { (Cukup) }\end{array}$ & $\begin{array}{c}0,29 \\
\text { (sukar) }\end{array}$ \\
\hline
\end{tabular}

Berdasarkan perhitungan di atas, terlihat bahwa kelima item soal tes kemampuan pemecahan masalah matematis siswa valid dan reliabel. Tetapi terdapat satu soal yang sukar sehingga diputuskan bahwa instrumen tes yang akan digunakan dalam penelitian yaitu nomor 1, 2, 3 dan 4 .

\section{HASIL DAN PEMBAHASAN}

Berdasarkan hasil analisis data, peneliti menemukan 4 jenis kesalahan yang dilakukan siswa dalam menyelesaikan soal pemecahan masalah matematika berdasarkan Teori Newman. Seluruh tipe kesalahan yang dilakukan dan jumlah kesalahan yang dilakukan siswa dapat dilihat pasa Tabel 2 . 
Table 2. Rekapitulasi Hasil Jawaban Siswa Per Butir Soal

\begin{tabular}{ccccc}
\hline No & \multicolumn{4}{c}{ Jenis Kesalahan } \\
\cline { 2 - 5 } Soal & $\begin{array}{c}\text { Memahami } \\
\text { Masalah }\end{array}$ & Transformasi & $\begin{array}{c}\text { Keterampilan } \\
\text { Proses }\end{array}$ & $\begin{array}{c}\text { Penulisan } \\
\text { Jawaban } \\
\text { Akhir }\end{array}$ \\
\hline 1 & 15 & 17 & 12 & 23 \\
\hline 2 & 11 & 11 & 10 & 13 \\
\hline 3 & 17 & 20 & 15 & 16 \\
\hline 4 & 16 & 16 & 11 & 18 \\
\hline
\end{tabular}

Tabel 2 menjelaskan bahwa jenis kesalahan memahami masalah pada soal nomor 1 dilakukan oleh 15 siswa, nomor 2 dilakukan oleh 11 siswa, nomor 3 dilakukan oleh 17 siswa dan nomor 4 dilakukan oleh 16 siswa. Jenis kesalahan transformasi pada soal nomor 1 dilakukan oleh 17 siswa, nomor 2 dilakukan oleh 11 siswa, nomor 3 dilakukan oleh 20 siswa dan nomor 4 dilakukan oleh 16 siswa. Jenis kesalahan keterampilan proses pada soal nomor 1 dilakukan oleh 12 siswa, nomor 2 dilakukan oleh 10 siswa, nomor 3 dilakukan oleh 15 siswa dan nomor 4 dilakukan oleh 11 siswa. Jenis kesalahan penulisan jawaban akhir pada soal nomor 1 dilakukan oleh 23 siswa, nomor 2 dilakukan oleh 13 siswa, nomor 3 dilakukan oleh 16 siswa dan nomor 4 dilakukan oleh 18 siswa.

Bersadarkan kesalahan yang dilakukan siswa, selanjutnya dijelaskan hasil jawaban siswa yang mewakili setiap indikator kesalahan menurut Newman. Hasil jawaban siswa untuk kesalahan memahami masalah dapat dilihat pada Gambar 1.

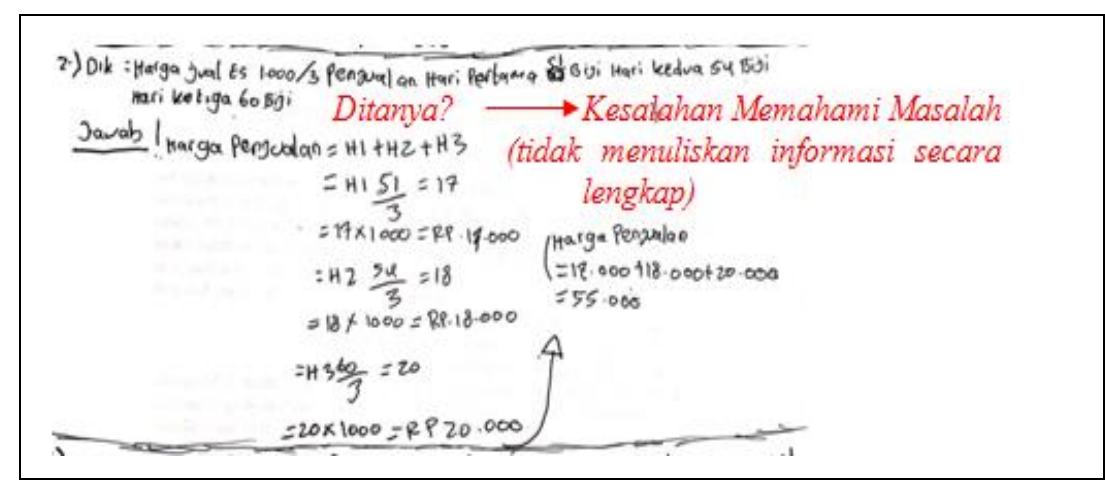

Gambar 1 Kesalahan memahami masalah 
Pada Gambar 1 terlihat bahwa siswa mampu menuliskan informasi yang ada pada soal, akan tetapi informasi yang dituliskan tidak lengkap. Kesalahan siswa dalam memahami masalah terjadi karena siswa tidak teliti dalam menuliskan informasi yang ada di soal.

Kesalahan kedua, yaitu kesalahan transformasi. Hasil jawaban siswa untuk kesalahan transformasi dapat dilihat pada Gambar 2.

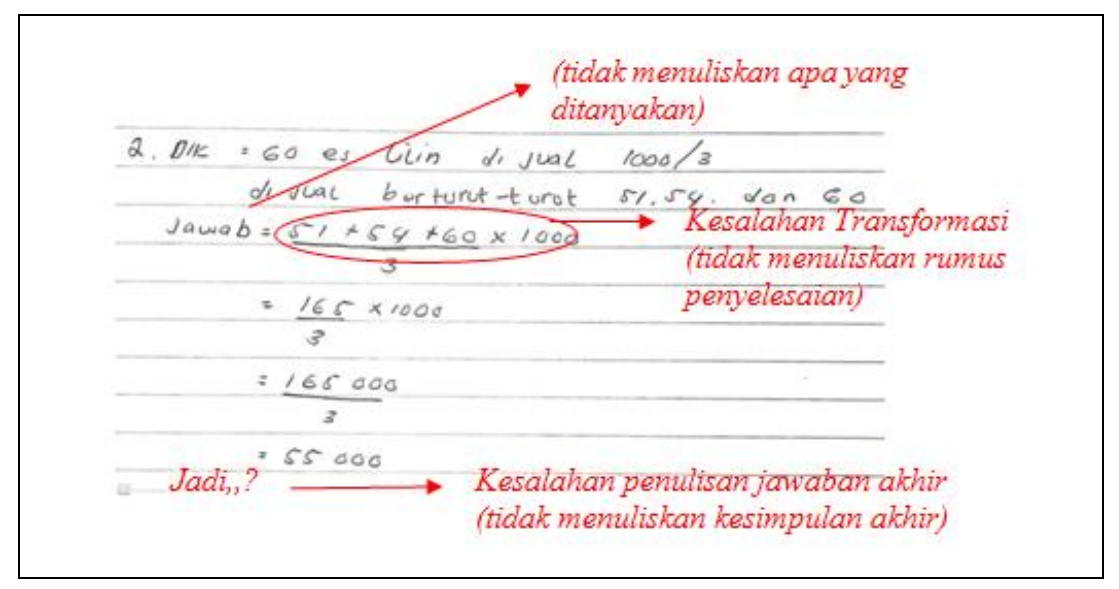

Gambar 2 Kesalahan Transformasi

Pada Gambar 2 terlihat bahwa siswa mampu menuliskan informasi yang ada pada soal, walaupun tidak lengkap. Siswa juga mampu melakukan pehitungan dengan benar, akan tetapi siswa tidak menuliskan rumus yang digunakan. Kesalahan siswa dalam transformasi terjadi karena siswa tidak memiliki keterampilan dalam mengubah bahasa soal kedalam model matematika.

Kesalahan ketiga, yaitu kesalahan keterampilan proses. Hasil jawaban siswa untuk kesalahan keterampilan proses dapat dilihat pada Gambar 3. 


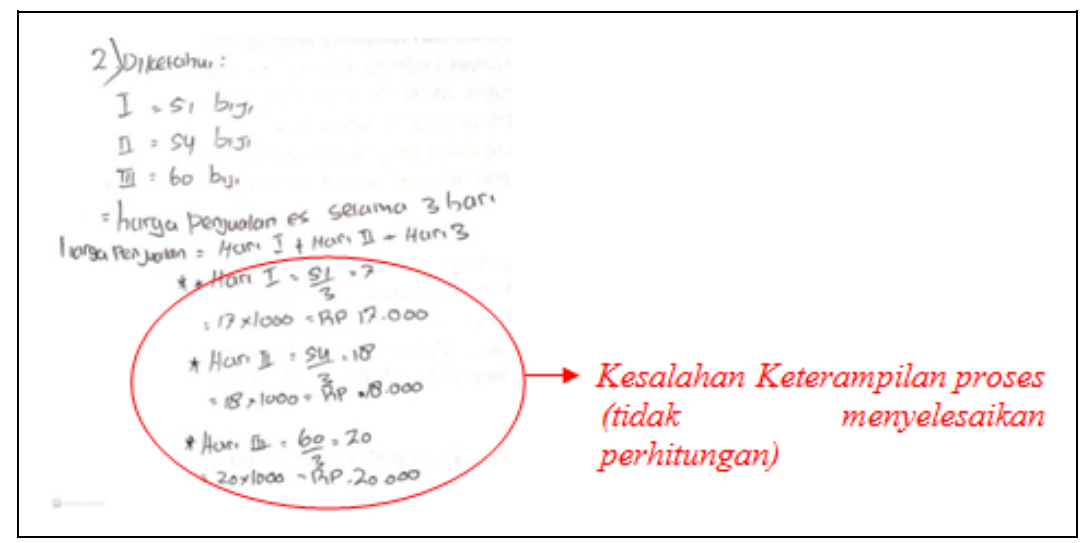

Gambar 3 Kesalahan Keterampilan Proses

Pada Gambar 3 terlihat bahwa siswa mampu menuliskan informasi yang ada pada soal dengan tepat dan mampu menuliskan rumus yang digunakan dengan benar. siswa juga melakukan proses perhitungan dengan benar akan tetapi siswa tidak menyelesaikan perhitungan sampai akhir, sehingga tidak memperoleh jawaban yang diharapkan. Kesalahan siswa dalam keterampilan proses terjadi karena siswa terburu-buru dalam menjawab sehingga tidak teliti dalam melakukan perhitungan.

Kesalahan Keempat, yaitu kesalahan Penulisan jawaban akhir. Hasil jawaban siswa untuk kesalahan penulisan jawaban akhir dapat dilihat pada Gambar 4.

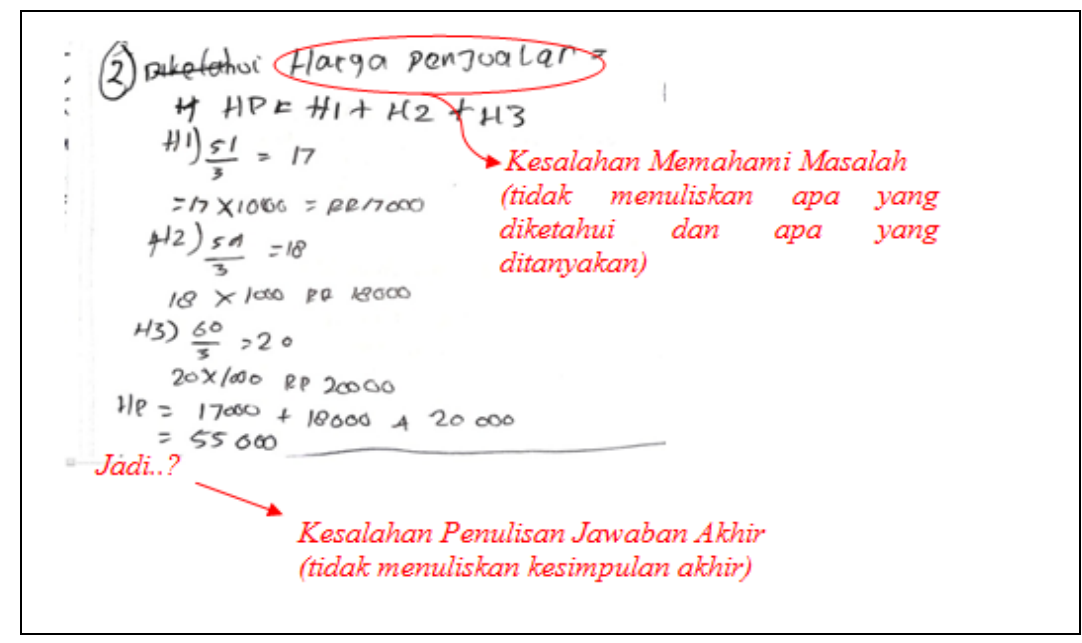

Gambar 4 Kesalahan Penulisan Jawaban Akhir 
Pada Gambar 4 terlihat bahwa siswa mampu menuliskan rumus yang digunakan dengan tepat dan mampu melakukan proses perhitungan dengan benar. Akan tetapi siswa tidak menuliskan kesimpulan akhir jawaban. Kesalahan siswa dalam penulisan jawaban akhir terjadi karena siswa tidak terbiasa menuliskan kesimpulan akhir.

\section{KESIMPULAN DAN SARAN}

Berdasarkan hasil penelitian dan pembahasan diperoleh kesimpulan bahwa kesalahan yang paling banyak dilakukan siswa adalah pada penulisan jawaban akhir, yang disebabkan karena siswa tidak memahami perintah yang ada di soal dengan baik. Kesalahan kedua yang paling banyak dilakukan yaitu kesalahan transformasi yang disebabkan karena siswa tidak memiliki keterampilan dalam mengubah bahasa soal kedalam model matematika. Kesalahan ketiga, yaitu kesalahan memahami masalah yang disebabkan karena siswa kurang teliti dalam menuliskan informasi yang ada di soal, dan tidak terbiasa menuliskan informasi yang ada di soal pada saat menyelesaikan soal matematika. Kesalahan keempat, yaitu kesalahan keterampilan proses yang disebabkan karena siswa kurang teliti dalam melakukan proses perhitungan.

\section{DAFTAR PUSTAKA}

[1] Rini Nuraeni, Suny Guinesya A dan Luvy Silviana Z, "Permasalahan Matematika Aritmatika Sosial Dalam Bentuk Cerita: Bagaimana Deskripsi Kesalahan-kesalahan Siswa," Jurnal Teorema: Teori dan Riset Matematika Vol. 5, No. 1/Maret 2020.

[2] [5] [7] Putu Nanci Riastini dan I Kadek Agus Mustika, "Pengaruh Model Polya Terhadap Kemampuan Pemecahan Masalah Matematika Siswa Kelas V SD," International Journal of Community Service Learning Vol. 1, No. 1/2017. 

Matematika I, (Singaraja: Universitas Pendidikan Ganesha, 2014).

[4] NCTM, Principles and Standards for School Mathematics, (United States of America: NCTM, 2000).

[6] Syarifah Fadilah, "Kemampuan Pemecahan Masalah Matematis Dalam Pembelajaran Matematika," Prosiding Seminar Nasional Pendidikan dan Penerapan MIPA, Universitas Negeri Yogyakarta, 2009.

[8] Junaika Hermaini dan Erdawati Nurdin,"Bagaimana Kemampuan Pemecahan Masalah Matematika Siswa dari Perspektif Minat Belajar," Journal for Research in Mathematics learning Vol. 3, No. 2/Juni 2020.

[9] Syamsul Hadi dan Novaliyosi, "TIMMS Indonesia (Trend In International Mathematics And Science Study)," Prosiding Seminar Nasional \& Call For Papers Januari 2019.

[10] Rizky Ristiani Fatmala, Ratna Sariningsih dan Luvi Sylviana Zhanti, "Analisis Kemampuan Pemecahan Masalah Matematis Siswa SMP Kelas VII Pada Materi Aritmatika Sosial,"Jurnal Pendidikan Matematika Vol. 4, No. 1/Mei 2020.

[11] [12][13] Fajriah, Salasi R dan Suryawati, "Analisis Kemampuan Problem Solving Dalam Menyelesaikan Materi Aritmatika Sosial Siswa Kelas VII SMP Negeri 7 Banda Aceh Tahun Ajaran 2015/2016," Jurnal Ilmiah Mahasiswa Pendidikan Matematika Vol. 1, No. 1/Agustus 2016. 